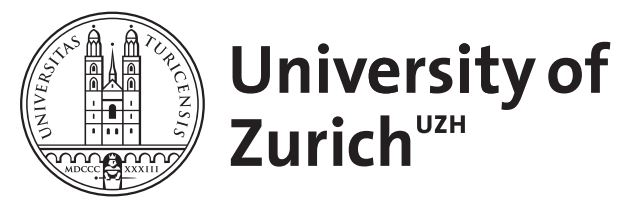

\title{
Immunological mechanisms in specific immunotherapy
}

\author{
Schmidt-Weber, Carsten B ; Blaser, Kurt
}

\begin{abstract}
Specific immunotherapy (SIT) represents the only curative treatment of allergy and is, therefore, of particular interest for immunological and pharmacological research. The current understanding of immunological mechanisms underlying SIT focuses on regulatory $\mathrm{T}$ cells ( $\mathrm{T}$ regs), which balance Th1 and Th2 effector functions. This ensures that allergens are recognized, but tolerated by the immune system. There is clear evidence that SIT restores the disturbed balance of $\mathrm{T}$ regs and effector cells in allergic patients. Current efforts are focused to improve SIT regimens to make them more applicable in atopy and asthma. The current review provides an overview on the mechanisms of SIT and possible adjuvant treatment strategies on the background of the $\mathrm{T}$ reg concept
\end{abstract}

DOI: https://doi.org/10.1007/s00281-003-0147-x

Posted at the Zurich Open Repository and Archive, University of Zurich

ZORA URL: https://doi.org/10.5167/uzh-156283

Journal Article

Published Version

Originally published at:

Schmidt-Weber, Carsten B; Blaser, Kurt (2004). Immunological mechanisms in specific immunotherapy. Seminars in Immunopathology, 25(3-4):377-390.

DOI: https://doi.org/10.1007/s00281-003-0147-x 


\author{
Carsten B. Schmidt-Weber • Kurt Blaser
}

\title{
Immunological mechanisms in specific immunotherapy
}

Received: 17 June 2003 / Accepted: 26 August 2003 / Published online: 24 October 2003 (C) Springer-Verlag is a part of Springer Sciences + Business Media 2003

\begin{abstract}
Specific immunotherapy (SIT) represents the only curative treatment of allergy and is, therefore, of particular interest for immunological and pharmacological research. The current understanding of immunological mechanisms underlying SIT focuses on regulatory $\mathrm{T}$ cells ( $\mathrm{T}$ regs), which balance Th1 and Th2 effector functions. This ensures that allergens are recognized, but tolerated by the immune system. There is clear evidence that SIT restores the disturbed balance of T regs and effector cells in allergic patients. Current efforts are focused to improve SIT regimens to make them more applicable in atopy and asthma. The current review provides an overview on the mechanisms of SIT and possible adjuvant treatment strategies on the background of the T reg concept.
\end{abstract}

Keywords Specific immunotherapy $\cdot$ Regulatory T cells $\cdot$ Allergy

\section{Introduction}

Allergies are mainly characterized by IgE-mediated immediate hypersensitivity against environmental antigens (allergens), which are normally tolerated by healthy individuals and which are non-pathogenic. The fact that the disease-relevant allergens are often known allows the specific peripheral tolerance to be restored by repeated injections of high doses of allergen over a long period of time. This specific immunotherapy (SIT) treatment, also termed allergen vaccination, is most successfully applied to allergies against insect venom [1] or to rhinitis [2]. It currently represents the only specific curative treatment of allergy. Ongoing studies are focusing on the molecular mechanisms, but also on improved treatment strategies, including the treatment of asthma and juvenile respiratory disease (Table 1). Studies in recent years have shown a significant treatment success and recommend SIT for treatment of allergies (Table 1). SIT of allergic rhinitis also reduces the risk of developing allergic asthma [3], and was shown to improve clinical symptoms of established disease $[4,5,6]$. Intensive research in the field of SIT has revealed molecular mechanisms

C. B. Schmidt-Weber $(\bullet) \cdot$ K. Blaser

Swiss Institute of Allergy and Asthma Research (SIAF), Obere Str. 22, 7270 Davos, Switzerland e-mail: csweber@siaf.unizh.ch·Tel.: +41-81-4100853·Fax: +41-81-4100840 


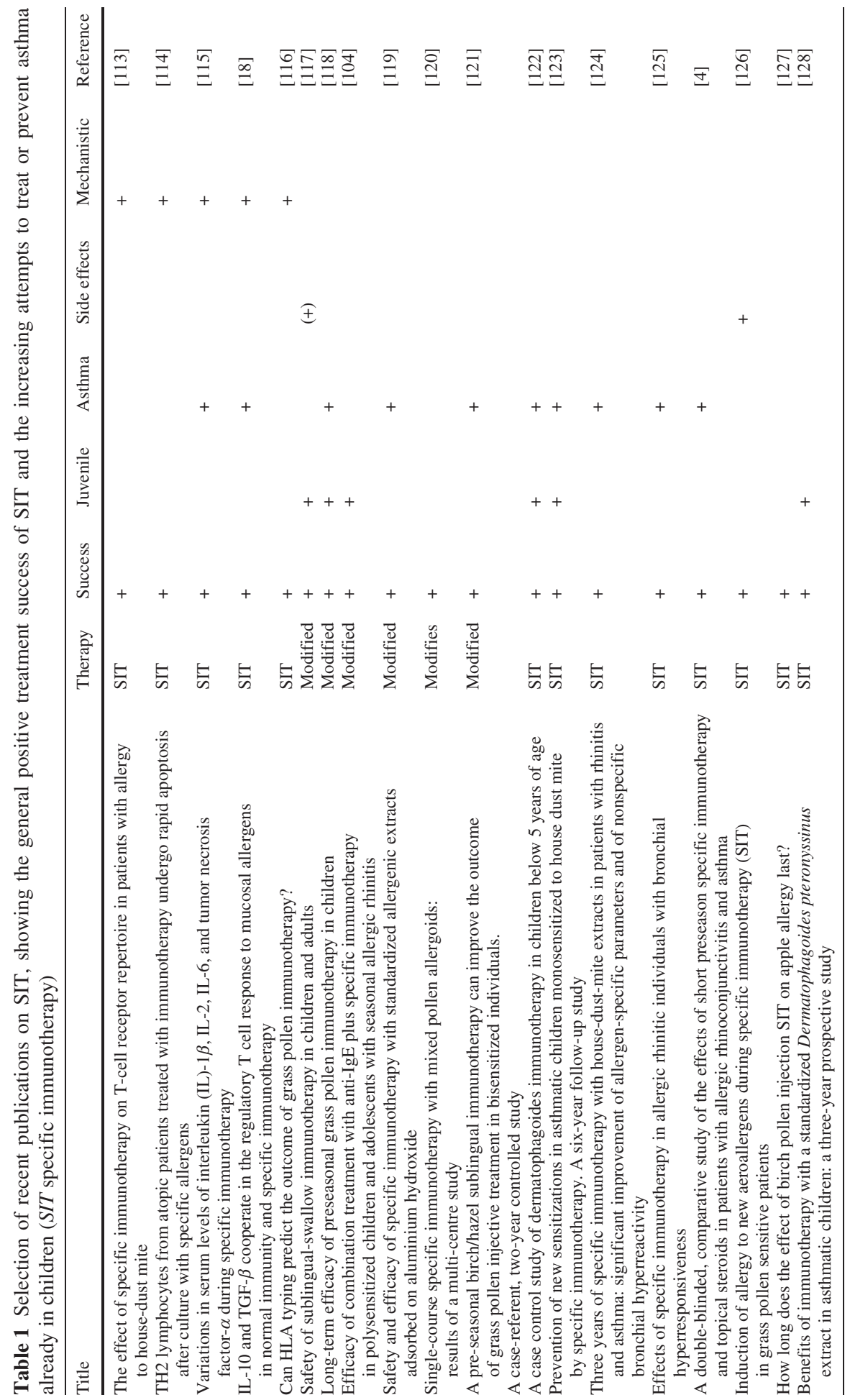


that control peripheral tolerance to allergen and which create the basis for the adaptation of SIT to more complex, atopic diseases.

\section{Cellular requirements for tolerance induction to allergen by SIT}

A key feature in the pathogenesis of allergy lies in the generation of allergen-specific IgE instead of IgG and IgA antibodies, which discriminates allergic from non-allergic inflammations. The immediate hypersensitivity reaction is initiated by an allergenic compound, generally soluble proteins or glycoproteins, penetrating through epithelial surfaces and then binding to specific IgE antibodies that were generated before by a first allergen contact. To generate allergen-specific IgE, it is necessary that naïve B cells recognize the allergen and receive help from IL-4-producing T cells, which is an essential cytokine for switching from IgM to IgE. The IL-4 production by $\mathrm{T}$ cells is also dependent on the presence of antigen [7]. The crucial role of the $T$ cell is further reflected by the fact that the degree of $\mathrm{T}$ cell activation strictly correlates with the number of low-affinity $\mathrm{IgE}$ receptor (CD23) -bearing B cells [8], eosinophil cationic protein (ECP) and other serum factors of allergic inflammation [9]. This clearly demonstrates that allergy is a T cell-dependent disease $[9,10]$. Thus, it is not surprising that peptides $[11,12]$ or engineered allergen vaccines $[13,14]$ lacking B cell epitopes are as efficient in SIT as native allergens. Peptides or engineered allergens appear in fact to be of advantage for the reduction of side effects of SIT, which appear when the allergen cross-links specific IgE on mast cells or basophils, bound to high-affinity FceRI, leading to activation and degranulation of the cells, and causing the allergic symptoms or even anaphylactic shock.

The SIT shows a reduction in allergen responsiveness in terms of skin prick test and immunological differences become apparent starting on day $7[15,16]$. It was a key finding that SIT against bee venom allergies induces T cell unresponsiveness (anergy) in vitro, 28 days following initiation of SIT $[16,17]$. These experiments support the concept that SIT restores the natural peripheral tolerance to allergens by re-introducing $\mathrm{T}$ cell tolerance. This concept of tolerance re-induction is supported by the molecular analysis of SIT and natural tolerance of allergens, as investigated in bee venom-induced immune responses of healthy and bee venom-allergic patients [15].

\section{Molecular mechanisms of SIT}

The ex vivo culture of PBMC isolated during the course of SIT showed increased IL-10 production by $\mathrm{T}$ cells along with the induction of $\mathrm{T}$ cell anergy. Later on, monocytes and B cells also produce IL-10 [15]. Similar observations were made with SIT directed against house dust mite or birch pollen, with the interesting difference that TGF- $\beta$ was also increasingly produced by $\mathrm{T}$ cells $[18,19]$, suggesting that allergen entering tissues via mucosal surfaces triggers different, TGF- $\beta$-dependent tolerization pathways. The T cell anergy could be prevented by the addition of IL-10-neutralizing antibodies or soluble TGF- $\beta$ receptors to the culture. The cytokines IL-10 and TGF- $\beta$ are both known to suppress T cell activity [20, 21]. Thus, SIT is accompanied by increasing suppression of the allergen-specific response. The changes on the $\mathrm{T}$ cell levels are followed by changes of the $\mathrm{B}$ cell phenotype. The cytokines IL-10 and TGF- $\beta$ also affect B cell activity towards IgG4 and IgA production. Both are suppressive for IgE. Accordingly, the allergen-specific isotype pro- 
Table 2 Phenotype of T regs controlling allergen-specific T cells

\begin{tabular}{lll}
\hline Phenotype & Function & Reference \\
\hline Antigen specific & Allergen-driven suppression & Akdis M, et al (submitted) \\
Non-proliferating & Terminally differentiated? & Akdis M, et al (submitted) \\
CD4 & T cell subset & [15], Akdis M, et al (submitted) \\
IL-10 & Suppression of T cells and APCs & [15], Akdis M, et al (submitted) \\
IL-10R & Differentiation into T reg? & Akdis M, et al (submitted) \\
TGF- $\beta$ & Suppression of T cells and APCs & {$[19]$} \\
CD25 & IL-2 receptor, survival and gowth of the T cells & {$[18]$} \\
CTLA-4 & Homolog of CD28, inhibits T cell activity & Akdis M, et al (submitted) \\
PD-1 & Receptor of the PDL1, inhibits T cell activity & Akdis M, et al (submitted) \\
CD105 & TGF- $\beta$ co-receptor, surface binding of TGF- $\beta$ & Schmidt-Weber CB,et al (submitted) \\
\hline
\end{tabular}

${ }^{\mathrm{a}} \mathrm{T}$ regulatory 1 cells in allergic and healthy immune response

${ }^{\mathrm{b}}$ Endoglin expression acts as a TGF- $\beta$ mediator of $\mathrm{CD} 25^{+}$regulatory T cells

file shifts during SIT towards normal $\operatorname{IgG} 4 / \operatorname{IgA}$ levels, and the ratio of specific $\operatorname{IgE}$ to IgG4 or IgA changes about 100-1,000-fold [18].

It could be shown that suppression not only plays a role in SIT but also maintains allergen tolerance in healthy individuals, who are sensitized to allergen, but do not show allergic symptoms. It was demonstrated that neutralization of IL-10 or TGF- $\beta$ reveals allergen responsiveness, particularly to allergens to which everyone is exposed, such as food allergens or house dust mites [18]. The T cells which produce these suppressive cytokines are low in IL-4 and IFN- $\gamma$, and thus are neither typical Th1 nor Th2 cells. They are called regulatory $\mathrm{T}$ cells ( $\mathrm{T}$ reg) $[22,23]$. $\mathrm{T}$ regs have been demonstrated to suppress immune reaction in several experimental systems in vitro and in vivo [24, 25, 26, 27, 28, 29, 30, 31]. Recent studies defined a CD25 $5^{+}$subset of T cells, which has a suppressive capacity in vitro and in vivo $[32,33,34,35,36]$. However, it is currently not fully established whether $\mathrm{CD}_{25}{ }^{+} \mathrm{T}$ cells are identical to IL-10- and/or TGF- $\beta$-producing $\mathrm{T}$ regs [35], since the suppression was in some cases contact dependent [34]. However, suppressive cytokines may be secreted into an immunological synapse [37] or may act in a surface-bound form on the target cell [38]. This CD25 ${ }^{+} \mathrm{T}$ reg subset also plays an important role in allergen-specific immunotherapy (SIT), since SIT-induced unresponsiveness could be prevented by depletion of $\mathrm{CD}^{2} 5^{+} \mathrm{T}$ cells in vitro [18], indicating that allergen reactivity is controlled by a CD25 ${ }^{+}$and IL-10/TGF- $\beta$-producing $\mathrm{T}$ reg population. The $\mathrm{T}$ reg phenotype controlling allergen-specific effector cells (Table 2), particularly of mucosal origin, may have a different phenotype from those $\mathrm{T}$ regs controlling autoantigens or tumor antigens. It should be considered that CD25 is not a satisfactory marker for $\mathrm{T}$ regs, since recently activated $\mathrm{T}$ cells also express CD25. Other activation markers, such as the cutaneous lymphocyte-activation antigen (CLA), are known to be on one hand an activation marker for recently activated $\mathrm{T}$ cells, but on the other hand are also indicative for terminal differentiated cells, which have already synthesized cytokines and secrete them without de novo synthesis following TCR engagement [39]. In analogy, it might be that T regs represent terminal differentiated cells derived from Th1 or Th2 memory cells. This hypothesis is in fact supported by the observation that $\mathrm{T}$ regs can be generated by CD46 stimulation of both memory and naïve $T$ cells [40]. The combination of CD25 with different activation markers, such as HLA II or CD69, may improve the identification of T regs [41]. An interesting development is the discovery of the FOXP3 transcription factor, which appears to be essential for the generation of $\mathrm{CD} 25^{+} \mathrm{T}$ regs $[42,43,44]$. In contrast to the CD25 gene, FOXP3 is not 
up-regulated following $\mathrm{T}$ cell activation; however, its nuclear/intracellular localization does not allow the use of this gene for diagnostic purposes. It is particularly interesting that FOXP3 is operatively involved in silencing the IL-2 gene expression, as demonstrated by FOXP3 overexpression in the Jurkat cell line [44]. Current studies are now focused on the effect of FOXP3 on T reg genes such as IL-10 and TGF- $\beta$.

Additional genes of diagnostic and pharmacological interest might become apparent when the molecular mechanisms underlying T cell suppression are fully understood. Initial studies on these mechanisms revealed that $\mathrm{T}$ cell suppression is linked to costimulation of T cells $[45,46,47,48]$. Biochemical analysis of costimulation revealed that the phosphatidyl inositol 3-kinase (PI3K) plays a key role in this process $[49,50]$. IL-10 suppresses the association of the PI3K with CD28 [51] as well as other costimulatory molecules, and thereby directly prevents costimulatory signals. The PI3K phosphorylates phosphatidyl inositol 2-phosphates (PIP2) into phosphatidyl 3-phosphates (PIP3). Interestingly, the immune inhibitory receptor of B cells or NK cells also addresses PIP3 lipids by activating PIP-phosphatases (e.g., SHIP; [52]), suggesting that prevention of PIP3 increases represents a general principle of immune suppression. The PIP3 lipids recruit molecules to the membrane, which contain pleckstrin or FYVE domains. One of the best known downstream targets of PI3K is the PKB or Akt kinase, which regulates diverse cellular processes such as proliferation and apoptosis [53].

The PI3K is, however, not only stimulated by costimulatory molecules. It is also a target for growth factor-mediated signals, including IL-2 and IL-4. Therefore, PIP3 levels can reflect multiple signals from the current environment of $\mathrm{T}$ cells, which will influence suppressive mechanisms. The PKB/Akt kinase collectively converts these signals in proliferation and/or survival signals. Recent investigations in our laboratory showed that IL-10 and TGF- $\beta$ induce a negative feedback on PIP3 mobilization by inducing the phosphatidylinositol phosphatase PTEN (C.B. Schmidt-Weber, unpublished results), which is otherwise induced by CD28 engagement as a natural recovery mechanism of PIP3-mediated activation [54]. In contrast to IL-10, TGF- $\beta$ mobilizes the SMAD2/3-4 complex, which interacts with other transcription factors to bind DNA elements that will down-regulate expression of the particular gene [55]. Alternative means of TGF- $\beta$ suppression would include the transforming growth factor-activated kinase-1 (TAK1) or the activation of phosphatases [56], which could immediately block or reduce signal transduction of TCR-mediated signals [57]. The suppression of $\mathrm{CD} 25^{+} \mathrm{T}$ cells is contact mediated, but the molecular details are currently unknown [58]. Further research will be necessary to define tissue conditions where suppression operates to control peripheral tolerance and affect SIT.

\section{The T reg concept}

It was originally believed that $\mathrm{Th} 2$ cells can be inhibited, if $\mathrm{T}$ cell differentiation is skewed towards Th1 cells, lacking IL-4 or IL-13 for IgE isotype switching. The current understanding of $\mathrm{T}$ cell regulation favors a relationship of $\mathrm{T}$ cell populations where Th0, Th1 or Th2 cells are in a balance with a regulatory $\mathrm{T}$ cell population ( $\mathrm{T}$ effector/T reg). The allergy relevant Th2 cells, producing typically IL-4, IL-5 and IL-13, are generated by differentiation of naïve $\mathrm{T}$ cells recognizing processed and MHC class II-presented allergen by dendritic cells in the presence of IL-4. This cytokine is also needed for differentiation of the Th2 pathway, whereas IL-12 is required for Th1 differentiation [59]. The two pathways 
inhibit one other, which leads to the hypothesis that allergy emerges in consequence of reduced Th1 cell frequency (two population model). Since Th1 cells are generated by infections and other inflammatory reactions, it was hypothesized that the pathogen-low environment in industrialized countries allows a shift of the Th1-Th2 balance towards the proallergenic Th2 cells.

One obvious argument against the concept of Th1/Th2 balance, is that allergen-specific T cells express a Th2-like cytokine pattern not only in allergic, but also in healthy individuals [60]. Furthermore, it is important to notice that, although Th2 cells are important for IgE switching, IFN- $\gamma$ typically expressed by Th1 cells also plays an important role in tissue destruction in chronic disease, particularly in keratinocyte/epithelial cell death in atopic dermatitis and asthma [61, 62]. In severe asthma, IL-12 serum levels are in fact known to be elevated [63], and alveolar monocytes are also primed to produce more IL-12 compared to healthy individuals [64]. The cell death-inducing IFN- $\gamma$ in peripheral tissues can also be provided by Th2 cells, if they have been exposed to IL-12 [65], despite lower expression of the IL-12R [66]. Interestingly, the IL-12-primed Th2 cells keep their ability to produce IL-5 [67], which may be particularly relevant for asthma. Taken together, these studies show that, although $\mathrm{T}$ cell differentiation towards Th1 and Th2 cells is important, the balance will not determine whether $\mathrm{T}$ cells become pathogenic or not. The fact that it is not Th1/Th2 balance, but rather the $\mathrm{T}$ effector/T reg balance that determines the general outcome of an immune response to given antigen [21, 68, 69] represents the current concept. Although a shift in T cell populations lies beneath this concept, it does not necessarily depend on a distinct Th2 cell subset as a cause of allergy pathogenesis. This concept is likely to change the strategy in hygiene hypothesis-motivated studies in a sense that infections are important for the generation, maintenance and survival of $\mathrm{T}$ regs [70]. In fact, danger signals provided by viral or microbial infections are assumed to play an important role in the regulation of peripheral tolerance [71], which should be considered as contraindicative for SIT.

On the basis of the T reg concept, current research is focused on obvious questions of how $\mathrm{T}$ regs are generated and how the target cells are suppressed by the $\mathrm{T}$ regs. The answer to these questions will allow SIT strategies to be improved and provide keys for improving induction and maintenance of peripheral $\mathrm{T}$ cell tolerance to allergen.

\section{New therapeutic approaches}

The change in immunological concepts is likely to affect the therapeutic rationale for the design of SIT. Adjuvant therapies are likely to improve the treatment efficacy if applied in a regimen supporting tolerance re-induction.

\section{Vaccine optimization}

The most obvious improvement of SIT is the generation of optimized allergens, reducing unwanted IgE-mediated side effects. Successful allergen engineering included fragmentation of the allergen [72], destruction of three-dimensional structure by di-/trimerization [13], mutagenesis of B cell epitopes by site-directed mutagenesis [73], dissection of the allergen in peptides $[74,75]$ or by fusion of several different major allergens into a single 
molecule (Kussebi et al., unpublished results). Besides the increased safety of these vaccines, it may be an advantage that the vaccine is not subjected to IgE-facilitated antigen presentation [76], which is supposed to further enhance IgE production in secondary responses. Is efficient antigen presentation also required for the activation and/or generation of $\mathrm{T}$ regs? This question remains open, since the origin of $\mathrm{T}$ regs and the mechanism of $\mathrm{T}$ reg-mediated suppression is not yet completely understood.

A broader range of indications of SIT for multiple forms of allergy requires the design of vaccines covering several allergen specificities. Ubiquitous allergens such as Bet V1, which cross-react with multiple allergens of other allergenic sources, may be engineered by $\mathrm{T}$ cell epitope shuffling to generate super-vaccines covering multiple specificities.

Adjuvants in SIT: cyclosporine A and rapamycin

The activity of $\mathrm{T}$ regs is at least limited in vitro by IL-2 [77, 78, 79, 80] and IL-15 [81, 82]. These cytokines can resolve T cell unresponsiveness (anergy) and prohibit anergy induction by IL-10 [77, 78, 79, 80]. Since both cytokines are secreted in conditions of acute inflammation, it appears that a balance of $\mathrm{T}$ regs and $\mathrm{T}$ effectors can only be established if acute inflammation is controlled. Thus, it would be favorable to use anti-inflammatory drugs to facilitate SIT against multiple allergenic responses and if unknown allergens contribute to perpetuation of the allergic inflammation. Cyclosporine A (CsA) and rapamycin efficiently block IL-2 expression and may help generate a pro-tolerogenic microenvironment. However, CsA [83] and rapamycin [84] are also known to inhibit the IL-10 gene expression and may, therefore, delay or block $\mathrm{T}$ reg activity, possibly preventing re-induction of peripheral tolerance.

Adjuvants in SIT: anti-histamines and other non-steroidal anti-inflammatory drugs

Non-steroidal anti-inflammatory drugs (NSAIDs) are commonly used in anti-inflammatory therapy and generally address $\mathrm{G}$ protein-coupled receptors (GPCR; [77, 78, 79, 80]). These GPCR are expressed on smooth muscle, epithelia and endothelial cells and induce contraction, vasodilatation and various other inflammatory reactions. For example, GPCR agonists or antagonists are used as therapies for asthma either by promoting airway smooth muscle relaxation (beta2 adrenergic receptor agonists) or by inhibiting inflammation in the nasal mucosa and airways (cysteinyl leukotriene receptor antagonists; [85]). Recent studies showed that GPCR can negatively regulate T cell activation [86, 87, 88, 89, 90, 91], mediated by the activation of the adenylate cyclase (AC) and subsequently increased intracellular cAMP [92, 93, 94]. Thus, IgE-triggered mast cell-released mediators negatively feedback on the $\mathrm{T}$ cell population, which is responsible for the initiation of $\mathrm{IgE}$ antibodies by B cells. Histamine, prostaglandins (PG) and leukotrienes (LT) are recognized by GPCR, of which four are known for $\mathrm{PGE}_{2}$ (EP1-4), two for $\mathrm{PGD}_{2}$ (DP, CRTH2), four for histamine (HR1-4), two for $\mathrm{LTB}_{4}$ and two for cysteinyl LT. All of these GPCRs can either signal via the phospholipase $\mathrm{C}$ pathway to mobilize $\mathrm{Ca}^{2+}$ transients or via activation of the $\mathrm{AC}$, increasing intracellular cAMP. For T cells expressing H2R, it was shown that the histamine-induced cAMP pathway mobilizes protein kinase A (PKA), which negatively regulates T cell proliferation [87] by down-regulation of IL-2 and IFN- $\gamma[95,96]$ and by increased IL-10 production [97]. This could also be shown for T cells isolated from asthmatic patients [98]. We recently demonstrated that histamine enhances the responsiveness of 
Th2 cells to TGF- $\beta$ in an H2R-dependent fashion, resulting in more efficient IL-4 suppression by TGF- $\beta$ [99]. The latter findings indicate that GPCR signaling is tied into the regulatory network of suppressive cytokines, but it is not clear under which circumstances GPCR ligands enhance or reduce T reg-mediated suppression. Although the effect of antiGPCR supplemented SITs were not studied in view of T cell immunology, anti-H1R antagonists were successfully used to reduce side effects of the treatment [100, 101, 102]. Since the antagonists are specific, histamine can still act on H2R to suppress T cells under these treatment regimens. Interestingly a recent study demonstrated that anti-H1R therapy during the initial rush protocol improved treatment in the sense of reduced skin sensitivity and allergen-specific IgE [103], suggesting improved tolerance induction.

\section{Adjuvants in SIT: anti-IgE}

Anti-IgE treatment covers the advantages of reduced $\operatorname{IgE}$ binding to the vaccine, reducing the risk of side effects on one hand and limiting the release of mast cell mediators, which are the targets of NSAIDs, on the other. Initial studies demonstrate significantly decreased allergic symptoms in patients receiving SIT and anti-IgE compared to SIT alone; however, anti-IgE was given 12 weeks after the first vaccine [104]. Further studies are now required to verify an immunological improvement in terms of $\mathrm{T}$ cell tolerance and long-term efficacy of anti-IgE supplement of SIT.

\section{Adjuvants in SIT: steroids}

Although steroids are potent immunosuppressors, it is currently not clear whether and how steroids affect the regulation of peripheral tolerance. Steroids are assumed to suppress the immune system by blocking cytokine production by blocking a crucial transcription factor $(\mathrm{NF}-\kappa \mathrm{B})$ by transcriptional up-regulation of its natural, cellular inhibitor $\mathrm{I} \kappa \mathrm{B}$ [105]. However, steroids show more immediate effects and also induce long-lasting changes in the differentiation of T cells. Very soon (3-4 h) after systemic steroid administration, glucocorticoids induce a redistribution of cells, which can be measured as reduced $\mathrm{T}$ cell counts and increased NK cell numbers [106]. The disappearing T cells were shown to migrate into the bone marrow [106], but remaining T cells are functionally intact [107]. The redistribution is possibly mediated by the steroid-mediated suppression of the adhesion molecules CD62L and CD11a [108]. This redistribution also affects $\mathrm{T}$ regs, which are found more frequently in the peripheral blood following steroid treatment (Karagiannidis et al., unpublished results). The origin and the immunological consequence of this steroid effect is still unclear.

Steroids promote chromatin remodeling $[109,110]$, which is known to be an important event in the differentiation of $\mathrm{T}$ effector cells [111] and, therefore, affects long-lasting immunological memory. Although this effect of steroids is problematic because of its antigen unspecificity, it is interesting to note that in vitro differentiation of $\mathrm{T}$ cells in the presence of steroids promotes the generation of IL-10-expressing T cells [112]. Further studies are necessary to understand the relationship of steroids, T regs and SIT. However, in vitro studies suggest that steroids do not necessarily inhibit $\mathrm{T}$ regs, and thus may go well along with SIT. 


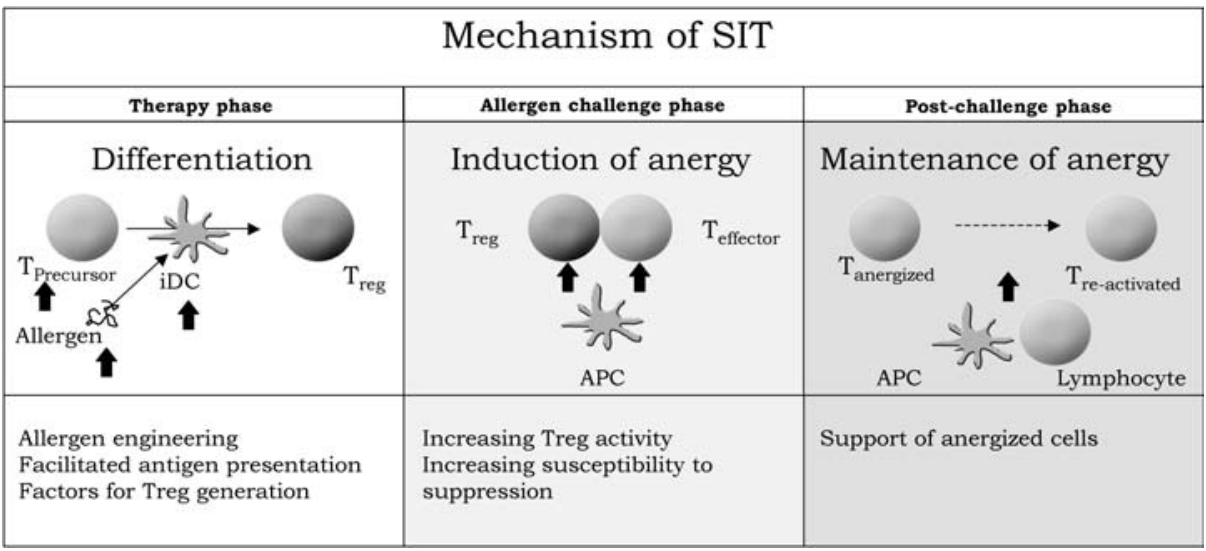

Fig. 1 The cartoon categorizes three different phases in the induction of T cell tolerance by SIT. Black arrows indicate therapeutic targets. Targets of therapy improvement may evolve not only from the therapy phase, which is critical for the differentiation of the $\mathrm{T}$ cells into $\mathrm{T}$ regs in the presence of antigen and $\mathrm{T}$ regpromoting APC such as iDC, but also in the allergen and post-allergen challenge phase. The allergen-challenge phase is characterized by the confrontation of the immune system with the allergen following immunotherapy, and $\mathrm{T}$ reg activity should induce anergy in upcoming $\mathrm{T}$ effector cells. Following this anergy induction phase, anergized cells are subjected to the microenvironment, which may influence the anergized cells. In particular, inflammatory conditions providing IL-2 and IL-15 may be counter-productive and may break anergy, representing molecular targets for maintenance of anergized cells (SIT specific immunotherapy, $T$ reg regulatory T cell, $A P C$ antigen-presenting cells, $i D C$ immature dendritic cells)

\section{Conclusion}

Although the potential of SIT is currently not fully used for the treatment of allergies, it has been proven as the only curative and non-symptomatic treatment of allergy. The analysis of underlying mechanisms of SIT indicate that generation of T regs, which control peripheral tolerance, is a key to treatment success. Available drugs and novel molecular targets are currently being tested to interfere with the differentiation of $\mathrm{T}$ regs, induction and maintenance of T cell suppression (Fig. 1). Of great importance for SIT is the immunological monitoring of SIT and its progress into the post-challenge phase, which is important for the evaluation of treatment success, which in turn determines the treatment-duration. The understanding of $\mathrm{T}$ reg-mediated suppression is likely to facilitate the identification of specific, molecular targets and will also improve SIT strategies and monitoring.

\section{References}

1. Lerch E, Muller UR (1998) Long-term protection after stopping venom immunotherapy: results of restings in 200 patients. J Allergy Clin Immunol 101:606

2. Durham SR, Walker SM, Varga EM, et al (1999) Long-term clinical efficacy of grass-pollen immunotherapy. N Engl J Med 341:468

3. Bousquet J, Demoly P, Michel FB (2001) Specific immunotherapy in rhinitis and asthma. Ann Allergy Asthma Immunol 87:38

4. Rak S, Heinrich C, Jacobsen L, et al (2001) A double-blinded, comparative study of the effects of short preseason specific immunotherapy and topical steroids in patients with allergic rhinoconjunctivitis and asthma. J Allergy Clin Immunol 108:921 
5. Gruber W, Eber E, Mileder P, et al (1999) Effect of specific immunotherapy with house dust mite extract on the bronchial responsiveness of paediatric asthma patients. Clin Exp Allergy 29:176

6. Cantani A, Arcese G, Lucenti P, et al (1997) A three-year prospective study of specific immunotherapy to inhalant allergens: evidence of safety and efficacy in 300 children with allergic asthma. J Invest Allergol Clin Immunol 7:90

7. Carballido JM, Faith A, Carballido-Perrig N, et al (1997) The intensity of T cell receptor engagement determines the cytokine pattern of human allergen-specific T helper cells. Eur J Immunol 27:515

8. Walker C, Bode E, Boer L, et al (1992) Allergic and nonallergic asthmatics have distinct patterns of Tcell activation and cytokine production in peripheral blood and bronchoalveolar lavage. Am Rev Respir Dis 146:109

9. Walker C, Kagi MK, Ingold P, et al (1993) Atopic dermatitis: correlation of peripheral blood T cell activation, eosinophilia and serum factors with clinical severity. Clin Exp Allergy 23:145

10. Walker C, Virchow JC Jr, Bruijnzeel PL, et al (1991) T cell subsets and their soluble products regulate eosinophilia in allergic and nonallergic asthma. J Immunol 146:1829

11. Blaser K, Carballido J, Faith A, et al (1998) Determinants and mechanisms of human immune responses to bee venom phospholipase A2. Int Arch Allergy Immunol 117:1

12. Durham SR, Till SJ (1998) Immunologic changes associated with allergen immunotherapy. J Allergy Clin Immunol 102:157

13. Vrtala S, Hirtenlehner K, Susani M, et al (2001) Genetic engineering of a hypoallergenic trimer of the major birch pollen allergen Bet v 1. FASEB J 15:2045

14. Valenta R, Kraft D (2001) Recombinant allergen molecules: tools to study effector cell activation. Immunol Rev 179:119

15. Akdis CA, Blaser K (1999) IL-10-induced anergy in peripheral T cell and reactivation by microenvironmental cytokines: two key steps in specific immunotherapy. FASEB J 13:603

16. Akdis CA, Blesken T, Akdis M, et al (1998) Role of interleukin 10 in specific immunotherapy. J Clin Invest 102:98

17. Bellinghausen I, Metz G, Enk AH, et al (1997) Insect venom immunotherapy induces interleukin-10 production and a Th2-to-Th1 shift, and changes surface marker expression in venom-allergic subjects. Eur J Immunol 27:1131

18. Jutel M, Akdis M, Budak F, et al (2003) IL-10 and TGF-beta cooperate in the regulatory T cell response to mucosal allergens in normal immunity and specific immunotherapy. Eur J Immunol 33:1205

19. Jutel M, Akdis M, Budak F, et al (2001) IL-10 and TGF- $\beta$ cooperate in inducing peripheral T cell tolerance during specific immunotherapy with inhalant allergens and during natural allergen exposure. $\mathrm{J}$ Allergy Clin Immunol 107:S90

20. Schmidt-Weber CB, Blaser K (2002) T-cell tolerance in allergic response. Allergy 57:762

21. Schmidt-Weber CB, Kunzmann S, Blaser K (2002) TGF-beta-mediated control of allergen-specific Tcell responses. Curr Allergy Asthma Rep 2:259

22. Chen Y, Kuchroo VK, Inobe J, et al (1994) Regulatory T cell clones induced by oral tolerance: suppression of autoimmune encephalomyelitis. Science 265:1237

23. Groux H, Bigler M, Vries JE de, Roncarolo MG (1996) Interleukin-10 induces a long-term antigenspecific anergic state in human $\mathrm{CD}^{+}{ }^{+} \mathrm{T}$ cells. J Exp Med 184:19

24. Asseman C, Mauze S, Leach MW, et al (1999) An essential role for interleukin 10 in the function of regulatory T cells that inhibit intestinal inflammation. J Exp Med 190:995

25. Groux H, O'Garra A, Bigler M, et al (1997) A Cd4(+) T-cell subset inhibits antigen-specific T-cell responses and prevents colitis. Nature 389:737

26. Qin L, Ding Y, Pahud DR, et al (1997) Adenovirus-mediated gene transfer of viral interleukin-10 inhibits the immune response to both alloantigen and adenoviral antigen. Hum Gene Ther 8:1365

27. Cobbold S, Waldmann H (1998) Infectious tolerance. Curr Opin Immunol 10:518

28. D'Orazio TJ, Niederkorn JY (1998) A novel role for TGF-beta and IL-10 in the induction of immune privilege. J Immunol 160:2089

29. Zhai Y, Kupiec-Weglinski JW (1999) What is the role of regulatory T cells in transplantation tolerance? Curr Opin Immunol 11:497

30. Mottet C, Uhlig HH, Powrie F (2003) Cutting edge: cure of colitis by CD4(+)CD25(+) regulatory T cells. J Immunol 170:3939

31. Maloy KJ, Salaun L, Cahill R, et al (2003) $\mathrm{CD} 4^{+} \mathrm{CD} 25^{+} \mathrm{T}(\mathrm{R})$ cells suppress innate immune pathology through cytokine-dependent mechanisms. J Exp Med 197:111

32. Suri-Payer E, Amar AZ, Thornton AM, et al (1998) CD4 ${ }^{+} \mathrm{CD} 25^{+} \mathrm{T}$ cells inhibit both the induction and effector function of autoreactive $\mathrm{T}$ cells and represent a unique lineage of immunoregulatory cells. J Immunol 160:1212 
33. Cederbom L, Hall $\mathrm{H}$, Ivars $\mathrm{F}(2000) \mathrm{CD} 4^{+} \mathrm{CD} 25^{+}$regulatory $\mathrm{T}$ cells down-regulate co-stimulatory molecules on antigen-presenting cells. Eur J Immunol 30:1538

34. Thornton AM, Shevach EM (1998) $\mathrm{CD}^{+} \mathrm{CD} 25^{+}$immunoregulatory $\mathrm{T}$ cells suppress polyclonal $\mathrm{T}$ cell activation in vitro by inhibiting interleukin 2 production. J Exp Med 188:287

35. Shevach EM, McHugh RS, Piccirillo CA, et al (2001) Control of T-cell activation by CD4+ CD25+ suppressor T cells. Immunol Rev 182:58

36. Jonuleit H, Schmitt E, Kakirman H, et al (2002) Infectious tolerance: human CD25(+) regulatory T cells convey suppressor activity to conventional CD4(+) T helper cells. J Exp Med 196:255

37. Stinchcombe JC, Griffiths GM (2001) Normal and abnormal secretion by haemopoietic cells. Immunology 103:10

38. Nakamura K, Kitani A, Strober W (2001) Cell contact-dependent immunosuppression by $\mathrm{CD} 4(+) \mathrm{CD} 25(+)$ regulatory $\mathrm{T}$ cells is mediated by cell surface-bound transforming growth factor beta. J Exp Med 194:629

39. Akdis M, Akdis CA, Weigl L, et al (1997) Skin-homing, $\mathrm{CLA}^{+}$memory T cells are activated in atopic dermatitis and regulate IgE by an IL-13-dominated cytokine pattern: IgG4 counter-regulation by CLAmemory T cells. J Immunol 159:4611

40. Kemper C, Chan AC, Green JM, et al (2003) Activation of human CD4 ${ }^{+}$cells with CD3 and CD46 induces a T-regulatory cell 1 phenotype. Nature 421:388

41. Wolf M, Schimpl A, Hunig T (2001) Control of T cell hyperactivation in IL-2-deficient mice by $\mathrm{CD}^{+} \mathrm{CD} 25^{-}$and $\mathrm{CD} 4^{+} \mathrm{CD} 25^{+} \mathrm{T}$ cells: evidence for two distinct regulatory mechanisms. Eur J Immunol 31:1637

42. Fontenot JD, Gavin MA, Rudensky AY (2003) Foxp3 programs the development and function of CD4(+)CD25(+) regulatory T cells. Nat Immunol 4:330

43. Hori S, Nomura T, Sakaguchi S (2003) Control of regulatory T cell development by the transcription factor Foxp3. Science 299:1057

44. Schubert LA, Jeffery E, Zhang Y, et al (2001) Scurfin (FOXP3) acts as a repressor of transcription and regulates T cell activation. J Biol Chem 276:37672

45. Guerder S, Flavell RA (1995) Costimulation in tolerance and autoimmunity. Int Rev Immunol 13:135

46. Liu L, Kuchroo VK, Weiner HL (1999) B7.2 (CD86) but not B7.1 (CD80) costimulation is required for the induction of low dose oral tolerance. J Immunol 163:2284

47. Adorini L (2000) Inhibition of dendritic cell costimulation associated with tolerance to allografts. Eur Cytokine Netw 11:508

48. Van Parijs L, Ibraghimov A, Abbas AK (1996) The roles of costimulation and Fas in T cell apoptosis and peripheral tolerance. Immunity 4:321

49. Pages F, Ragueneau M, Rottapel R, et al (1994) Binding of phosphatidylinositol-3-OH kinase to CD28 is required for T-cell signalling [published erratum appears in Nature (1994) 370:157]. Nature 369:327

50. Brennan P, Babbage JW, Burgering BM, et al (1997) Phosphatidylinositol 3-kinase couples the interleukin-2 receptor to the cell cycle regulator E2F. Immunity 7:679

51. Joss A, Akdis M, Faith A, et al (2000) IL-10 directly acts on T cells by specifically altering the CD28 co-stimulation pathway. Eur J Immunol 30:1683

52. Ravetch JV, Lanier LL (2000) Immune inhibitory receptors. Science 290:84

53. Marte BM, Downward J (1997) PKB/Akt: connecting phosphoinositide 3-kinase to cell survival and beyond. Trends Biochem Sci 22:355

54. Schmidt-Weber CB, Wohlfahrt JG, Akdis C, et al (2002) The phosphatidylinositol phosphatase PTEN is under control of costimulation and regulates proliferation in human T cells. Eur J Immunol 32:1196

55. Dong Y, Tang L, Letterio JJ, et al (2001) The Smad3 protein is involved in TGF-beta inhibition of class II transactivator and class II MHC expression. J Immunol 167:311

56. Petritsch C, Beug H, Balmain A, et al (2000) TGF-beta inhibits p70 S6 kinase via protein phosphatase 2A to induce G(1) arrest. Genes Dev 14:3093

57. Choudhry MA, Sir O, Sayeed MM (2001) TGF-beta abrogates TCR-mediated signaling by upregulating tyrosine phosphatases in T cells. Shock 15:193

58. Shevach EM (2002) $\mathrm{CD} 4^{+} \mathrm{CD} 25^{+}$suppressor T cells: more questions than answers. Nat Rev Immunol 2:389

59. Abbas AK, Murphy KM, Sher A (1996) Functional diversity of helper T lymphocytes. Nature 383:787

60. Li Y, Simons FE, Jay FT, et al (1996) Allergen-driven limiting dilution analysis of human IL-4 and IFN-gamma production in allergic rhinitis and clinically tolerant individuals. Int Immunol 8:897

61. Trautmann A, Schmid-Grendelmeier P, Kruger K, et al (2002) T cells and eosinophils cooperate in the induction of bronchial epithelial cell apoptosis in asthma. J Allergy Clin Immunol 109:329

62. Trautmann A, Akdis M, Kleemann D, et al (2000) T cell-mediated Fas-induced keratinocyte apoptosis plays a key pathogenetic role in eczematous dermatitis. J Clin Invest 106:25 
63. Wong CK, Ho CY, Ko FW, et al (2001) Proinflammatory cytokines (IL-17, IL-6, IL-18 and IL-12) and Th cytokines (IFN-gamma, IL-4, IL-10 and IL-13) in patients with allergic asthma. Clin Exp Immunol 125:177

64. Magnan A, Pee D van, Bongrand P, et al (1998) Alveolar macrophage interleukin (IL)-10 and IL-12 production in atopic asthma. Allergy 53:1092

65. Smits HH, Rietschoten JG van, Hilkens CM, et al (2001) IL-12-induced reversal of human Th2 cells is accompanied by full restoration of IL-12 responsiveness and loss of GATA-3 expression. Eur J Immunol 31:1055

66. Hilkens CM, Messer G, Tesselaar K, et al (1996) Lack of IL-12 signaling in human allergen-specific Th2 cells. J Immunol 157:4316

67. De Wit D, Amraoui Z, Vincart B, et al (2000) Helper T-cell responses elicited by Der p 1-pulsed dendritic cells and recombinant IL-12 in atopic and healthy subjects. J Allergy Clin Immunol 105:346

68. Sakaguchi S (2000) Regulatory T cells: key controllers of immunological self-tolerance. Cell 101:455

69. Bellinghausen I, Knop J, Saloga J (2001) The role of interleukin 10 in the regulation of allergic immune responses. Int Arch Allergy Immunol 126:97

70. Caramalho I, Lopes-Carvalho T, Ostler D, et al (2003) Regulatory T cells selectively express toll-like receptors and are activated by lipopolysaccharide. J Exp Med 197:403

71. Matzinger P (1994) Tolerance, danger, and the extended family. Annu Rev Immunol 12:991

72. Vrtala S, Akdis CA, Budak F, et al (2000) T cell epitope-containing hypoallergenic recombinant fragments of the major birch pollen allergen, Bet v 1, induce blocking antibodies. J Immunol 165:6653

73. Ferreira F, Ebner C, Kramer B, et al (1998) Modulation of IgE reactivity of allergens by site-directed mutagenesis: potential use of hypoallergenic variants for immunotherapy. FASEB J 12:231

74. Muller U, Akdis CA, Fricker M, et al (1998) Successful immunotherapy with T-cell epitope peptides of bee venom phospholipase A2 induces specific T-cell anergy in patients allergic to bee venom. J Allergy Clin Immunol 101:747

75. Oldfield WL, Larche M, Kay AB (2002) Effect of T-cell peptides derived from Fel d 1 on allergic reactions and cytokine production in patients sensitive to cats: a randomised controlled trial. Lancet 360:47

76. Neerven RJ van, Wikborg T, Lund G, et al (1999) Blocking antibodies induced by specific allergy vaccination prevent the activation of $\mathrm{CD}^{+} \mathrm{T}$ cells by inhibiting serum-IgE-facilitated allergen presentation. J Immunol 163:2944

77. Boussiotis VA, Freeman GJ, Berezovskaya A, et al (1997) Maintenance of human T cell anergy: blocking of IL-2 gene transcription by activated Rap1. Science 278:124

78. Beverly B, Kang SM, Lenardo MJ, et al (1992) Reversal of in vitro T cell clonal anergy by IL-2 stimulation. Int Immunol 4:661

79. Boussiotis VA, Barber DL, Nakarai T, et al (1994) Prevention of T cell anergy by signaling through the gamma c chain of the IL-2 receptor. Science 266:1039

80. Fortis C, Clementi E (1997) Reversible lymphocyte anergy during IL-2 therapy. Immunol Today 18:254

81. Akdis CA, Akdis M, Blesken T, et al (1996) Epitope-specific T cell tolerance to phospholipase A2 in bee venom immunotherapy and recovery by IL-2 and IL-15 in vitro. J Clin Invest 98:1676

82. Ewan PW (2001) New insight into immunological mechanisms of venom immunotherapy. Curr Opin Allergy Clin Immunol 1:367

83. Rafiq K, Charitidou L, Bullens DM, et al (2001) Regulation of the IL-10 production by human T cells. Scand J Immunol 53:139

84. Cohen SB, Parry SL, Feldmann M, et al (1997) Autocrine and paracrine regulation of human T cell IL-10 production. J Immunol 158:5596

85. Johnson EN, Druey KM (2002) Heterotrimeric G protein signaling: role in asthma and allergic inflammation. J Allergy Clin Immunol 109:592

86. Stankova J, Gagnon N, Rola-Pleszczynski M (1992) Leukotriene B4 augments interleukin-2 receptorbeta (IL-2R beta) expression and IL-2R beta-mediated cytotoxic response in human peripheral blood lymphocytes. Immunology 76:258

87. Vang T, Torgersen KM, Sundvold V, et al (2001) Activation of the COOH-terminal Src kinase (Csk) by cAMP-dependent protein kinase inhibits signaling through the T cell receptor. J Exp Med 193:497

88. Santamaria LF, Torres R, Ryder H, et al (1999) Prostaglandin E2 inhibits SEB-mediated induction of the cutaneous lymphocyte-associated antigen. Int Arch Allergy Immunol 118:351

89. Kabashima K, Saji T, Murata T, et al (2002) The prostaglandin receptor EP4 suppresses colitis, mucosal damage and CD4 cell activation in the gut. J Clin Invest 109:883

90. Poluektova LY, Huggler GK, Patterson EB, et al (1999) Involvement of protein kinase A in histaminemediated inhibition of IL-2 mRNA expression in mouse splenocytes. Immunopharmacology 41:77 
91. Jutel M, Watanabe T, Klunker S, et al (2001) Histamine regulates T-cell and antibody responses by differential expression of $\mathrm{H} 1$ and $\mathrm{H} 2$ receptors. Nature 413:420

92. Hur EM, Kim KT (2002) G protein-coupled receptor signalling and cross-talk. Achieving rapidity and specificity. Cell Signal 14:397

93. Brady AE, Limbird LE (2002) G protein-coupled receptor interacting proteins: emerging roles in localization and signal transduction. Cell Signal 14:297

94. Neves SR, Ram PT, Iyengar R (2002) G protein pathways. Science 296:1636

95. Chen D, Rothenberg EV (1994) Interleukin 2 transcription factors as molecular targets of cAMP inhibition: delayed inhibition kinetics and combinatorial transcription roles. J Exp Med 179:931

96. Osna N, Elliott K, Khan MM (2001) The effects of histamine on interferon gamma production are dependent on the stimulatory signals. Int Immunopharmacol 1:135

97. Osna N, Elliott K, Khan MM (2001) Regulation of interleukin-10 secretion by histamine in TH2 cells and splenocytes. Int Immunopharmacol 1:85

98. Hol BE, Krouwels FH, Bruinier B, et al (1993) Heterogeneous effects of histamine on proliferation of lung- and blood-derived T-cell clones from healthy and asthmatic persons. Am J Respir Cell Mol Biol 8:647

99. Kunzmann S, Mantel PY, Wohlfahrt JG, et al (2003) Histamine enhances TGF-beta mediated suppression of Th2 responses. FASEB J 17:1089

100. Nielsen L, Johnsen CR, Mosbech H, et al (1996) Antihistamine premedication in specific cluster immunotherapy: a double-blind, placebo-controlled study. J Allergy Clin Immunol 97:1207

101. Brockow K, Kiehn M, Riethmuller C, et al (1997) Efficacy of antihistamine pretreatment in the prevention of adverse reactions to Hymenoptera immunotherapy: a prospective, randomized, placebo-controlled trial. J Allergy Clin Immunol 100:458

102. Reimers A, Hari Y, Muller U (2000) Reduction of side-effects from ultrarush immunotherapy with honeybee venom by pretreatment with fexofenadine: a double-blind, placebo-controlled trial. Allergy $55: 484$

103. Muller U, Hari Y, Berchtold E (2001) Premedication with antihistamines may enhance efficacy of specific- allergen immunotherapy. J Allergy Clin Immunol 107:81

104. Kuehr J, Brauburger J, Zielen S, et al (2002) Efficacy of combination treatment with anti-IgE plus specific immunotherapy in polysensitized children and adolescents with seasonal allergic rhinitis. J Allergy Clin Immunol 109:274

105. Frieri M (1999) Corticosteroid effects on cytokines and chemokines. Allergy Asthma Proc 20:147

106. Fauci AS (1975) Mechanisms of corticosteroid action on lymphocyte subpopulations. I. Redistribution of circulating $\mathrm{T}$ and B lymphocytes to the bone marrow. Immunology 28:669

107. Balow JE, Hurley DL, Fauci AS (1975) Immunosuppressive effects of glucocorticosteroids: differential effects of acute vs chronic administration on cell-mediated immunity. J Immunol 114:1072

108. Bauer ME, Papadopoulos A, Poon L, et al (2002) Dexamethasone-induced effects on lymphocyte distribution and expression of adhesion molecules in treatment-resistant depression. Psychiatry Res 113:1

109. Fryer CJ, Archer TK (1998) Chromatin remodelling by the glucocorticoid receptor requires the BRG1 complex. Nature 393:88

110. Fletcher TM, Ryu BW, Baumann CT, et al (2000) Structure and dynamic properties of a glucocorticoid receptor-induced chromatin transition. Mol Cell Biol 20:6466

111. Agarwal S, Rao A (1998) Modulation of chromatin structure regulates cytokine gene expression during T cell differentiation. Immunity 9:765

112. Barrat FJ, Cua DJ, Boonstra A, et al (2002) In vitro generation of interleukin 10-producing regulatory CD4(+) T cells is induced by immunosuppressive drugs and inhibited by T helper type 1 (Th1)- and Th2-inducing cytokines. J Exp Med 195:603

113. Sade K, Kivity S, Levy A, et al (2003) The effect of specific immunotherapy on T-cell receptor repertoire in patients with allergy to house-dust mite. Allergy 58:430

114. Guerra F, Carracedo J, Solana-Lara R, et al (2001) TH2 lymphocytes from atopic patients treated with immunotherapy undergo rapid apoptosis after culture with specific allergens. J Allergy Clin Immunol 107:647

115. De Amici M, Puggioni F, Casali L, et al (2001) Variations in serum levels of interleukin (IL)-1beta, IL-2, IL-6, and tumor necrosis factor-alpha during specific immunotherapy. Ann Allergy Asthma Immunol 86:311

116. Fleva A, Daniilidis M, Sidiropoulos J, et al (2001) Can HLA typing predict the outcome of grass pollen immunotherapy? Exp Clin Immunogenet 18:13

117. Andre C, Vatrinet C, Galvain S, et al (2000) Safety of sublingual-swallow immunotherapy in children and adults. Int Arch Allergy Immunol 121:229 
118. Eng PA, Reinhold M, Gnehm HP (2002) Long-term efficacy of preseasonal grass pollen immunotherapy in children. Allergy 57:306

119. Wuthrich B, Gumowski PL, Fah J, et al (2001) Safety and efficacy of specific immunotherapy with standardized allergenic extracts adsorbed on aluminium hydroxide. J Invest Allergol Clin Immunol $11: 149$

120. Drachenberg KJ, Proll S, Urban E, et al (2003) Single-course specific immunotherapy with mixed pollen allergoids: results of a multi-centre study. Allergol Immunopathol (Madr) 31:77

121. Cirla AM, Cirla PE, Parmiani S, et al (2003) A pre-seasonal birch/hazel sublingual immunotherapy can improve the outcome of grass pollen injective treatment in bisensitized individuals. A case-referent, two-year controlled study. Allergol Immunopathol 31:31

122. Di Bernardino C, Di Bernardino F, Colombo R, et al (2002) A case control study of dermatophagoides immunotherapy in children below 5 years of age. Allerg Immunol 34:56

123. Pajno GB, Barberio G, De Luca F, et al (2001) Prevention of new sensitizations in asthmatic children monosensitized to house dust mite by specific immunotherapy. A six-year follow-up study. Clin Exp Allergy 31:1392

124. Pichler CE, Helbling A, Pichler WJ (2001) Three years of specific immunotherapy with house-dustmite extracts in patients with rhinitis and asthma: significant improvement of allergen-specific parameters and of nonspecific bronchial hyperreactivity. Allergy 56:301

125. Grembiale RD, Camporota L, Naty S, et al (2000) Effects of specific immunotherapy in allergic rhinitic individuals with bronchial hyperresponsiveness. Am J Respir Crit Care Med 162:2048

126. Obtulowicz K, Cichocka-Jarosz E (1998) Induction of allergy to new aeroallergens during specific immunotherapy (SIT) in grass pollen sensitive patients. Allerg Immunol (Paris) 30:250

127. Asero R (2003) How long does the effect of birch pollen injection SIT on apple allergy last? Allergy 58:435

128. Pifferi M, Baldini G, Marrazzini G, et al (2002) Benefits of immunotherapy with a standardized Dermatophagoides pteronyssinus extract in asthmatic children: a three-year prospective study. Allergy $57: 785$ 